\title{
ISLAMIC RELIGIOUS EDUCATION LEARNING STRATEGY TO REALIZE EIGHT STUDENT CHARACTERS IN STATE ELEMENTARY SCHOOL 107405 SEI ROTAN
}

\author{
Ernawati* \\ *Teacher in Deli Serdang Regency, North Sumatra
}

\begin{abstract}
This study aims to determine: (1) the program carried out in 107405 Sei Rotan Public Elementary School in realizing eight student characters, (20 plans carried out by Islamic Religious Education teachers in realizing eight student characters in 107405 Sei Rotan Public Elementary School, (3) strategy what can be done by Islamic Religious Education teachers in realizing the eight characters of students, and (4) the implications arising from the strategies carried out by Islamic Religious Education teachers on the formation of student characters in practicing worship. The research method uses qualitative research, namely research conducted naturally by utilizing researchers as research instruments. The subjects of this study were Islamic Religious Education teachers, principals, and students. Data retrieved through observation, documentation, and interviews. Data is analyzed based on data reduction, data presentation, and drawing conclusions. The results of this research can be concluded as follows: (1) the program carried out by has accommodated the coaching of eight student characters (religious, honest, tolerance, hard work, creative, independent, democratic, and disciplined) through the $3 \mathrm{~S}$ program, duha prayers, midday prayers, commemoration of Islamic holidays, flag ceremonies, extracurricular activities (scouting, sports, and art), clean Friday activities, gymnastics, OSN activities, (2) planning by teachers of Education Islamic religion in realizing the eight characters of students is done by teachers by preparing learning plans based on the vision and mission of the school, competency standards, and also based on interesting and innovative learning patterns, (3) strategies undertaken by Islamic Religious Education teachers in the development of eight student characters implemented from the implementation of learning was interesting and fun shows an enthusiastic attitude towards learning carried out by the teacher, and (4) the implication of coaching the eight characters of students is a positive change in the character of students and achievement of learning outcomes.
\end{abstract}

Keywords: Learning Education, Caracters 


\section{INTRODUCTION}

Islamic Religious Education is expected to produce humans who always strive to perfect their faith, piety, and morals, and actively develop a dignified national civilization. Such humans are expected to be resilient in facing challenges, obstacles, and changes that arise in the association of societies in the local, national, regional and global scope.

The success of an education is very much determined by the teacher. Teachers are expected to develop learning methods according to competency standards and basic competencies. Achievement of all the basic competencies of commendable behavior can be done irregularly, the role of all elements of both the school, parents and the community is very important in supporting the successful achievement of the objectives of Islamic education. Suryosubroto, (2010: 22) said that the teaching and learning process contains two meanings, namely a series of stages or phases in learning something and can also mean as a series of design activities by the teacher, the implementation of activities until evaluation and follow -up programs.

Educator competence is very influential in supporting the learning process. Teacher competence in preparing, implementing, evaluating, and providing feed back. That is, the quality of learning with the teacher as implementing the learning process will determine the success of an Islamic Religious Education learning. There are at least 3 factors that influence success in learning, namely the goal factors, teacher factors, and student factors. The Islamic education system should contain educational goals, educational curricula, educators, students, educational methods, and educational evaluations. In order to achieve the objectives of Islamic religious education, all of the above components must be properly set. Potential learners both cognitive, affective, and psychomotor aspects must be truly achieved. So that students know what Islam is, skilled in carrying out Islamic sharia, and the most important is the values of Islamic teachings internalized in students in their daily lives in their environment.

\section{THEORITICAL REVIEW}

Muktar (2007: 12) states that the word strategy comes from the Latin, namely, 'strategia' which means the art of using plans to achieve goals. Initially, the term strategy was known in the military world primarily related to war, but that meaning has now expanded not only in conditions of war but also peacefully, and in various fields including 
economic, social, education, and so on. In learning strategies related to the approach in delivering material to students.

The best strategy in conveying knowledge is to be gentle so that students will be easy and quick to accept the material delivered. But the strategy referred to in this study is the strategy contained in a teacher to be transmitted to students so that students behave in accordance with what is desired by the curriculum. The strategy that exists in a teacher is a competency that must be possessed by a teacher.

According to the National Education System Law number 14 of 2005 concerning Teachers and Lecturers explains that a teacher must have four basic competencies in conducting the learning process. Competencies that must be possessed by teachers include: (1) pedagogical competencies, (2) personality competencies, (3) professional competencies, and (4) social competencies.

Depdiknas (2004: 9) states that pedagogical competence is the ability to manage learners' learning. The ability in question is the ability to plan teaching and learning programs, carry out interactions or manage teaching and learning processes, conduct assessments. Teachers as educators whose main task is to teach, must have personality characteristics that are very influential in the development of human resources, a steady personality of a teacher will set a good example for students and their communities, so that teachers will appear as people who are innocent and imitated ( teacher).

Muhibbin (2000: 225-226) asserted that the teacher's personality really determines whether he is a good educator and coach for his students, or will be a destroyer and destroyer for the future of his students, especially for young students (elementary level). The teacher's personality traits that can make a teacher successful include flexibility in his knowledge, openness in his psychology, flexibility in his psychomotor

Surya (2003: 138) states that personality competencies are personal competencies, namely the personal abilities of a teacher that are needed in order to become a good teacher. Anwar (2004: 63) argues that the teacher's personal abilities include: (1) the appearance of a positive attitude towards his overall duties as a teacher, (2) understanding comprehension and the appearance of the values held by a teacher, (3) personality, value of life attitude displayed in an effort to make themselves role models and role models for their students. 
Arikunto (1993: 239) states that personal competence requires teachers to have a strong personality so that it becomes a source of inspiration for students' subjects, and should be emulated by students. According to some of the above it can be concluded that the teacher's personal competence is reflected in indicators of attitude and example.

Surya (2003: 138) states that professional competence is a variety of abilities needed to realize itself as a professional teacher. The intended professional competence includes, expertise in their fields, namely the mastery of the material that must be taught along with the method, the sense of responsibility for their duties and a sense of togetherness with other teacher peers. Effective teachers are teachers who are able to bring their students successfully to achieve the objectives of teaching. If this professional competency was possessed by every teacher, surely the goal of national education would quickly be realized.

Arikunto (1993: 239) argues that social competence requires teachers to have good social communication skills with students, fellow teachers, principals, administrative staff, even with community members. Teacher social competence is reflected in teacher interaction with students, teacher interaction with the principal teacher interaction with coworkers, teacher interaction with parents, and teacher interaction with the community. If a teacher is capable of good social interaction then of course this will be a good example for students so that the character of students who want to be achieved in educational goals will be easily realized. The four teacher competencies outlined above are the benchmarks of the successful formation of student character in learning. If the teacher really has the four competencies in question then surely the decline in student morals that occurs at this time will be avoided.

Purwanto (2007: 11) states education is all efforts of adults in association with children to develop their body and spirit towards maturity. Syam (1988: 7) explains education is an activity and effort to improve one's personality that is spiritual and physical. From some of the definitions above, the researcher concludes that education is an effort to guide students to develop various potentials that exist in themselves so that they can form a better person.

Muhaimin (2010: 6) explained that Islamic Religious Education is one part of Islamic education. Daradjat (1992: 88) explains Islamic Education is an effort to guide and care for students so that later after completion of education can understand what is contained in the 
teachings of Islam as a whole. Live the meaning and purpose and purpose so that they can practice the teachings of the Islamic religion that they have adopted, as their outlook on life so they can bring salvation to the world and the hereafter.

Daradjat (1983: 72) states that the goal of Islamic education is to shape Muslim personality, that is, personality whose overall aspects are imbued by Islamic teachings. This goal is in accordance with the goal of national education which is to form Pancasila people who are devoted to God Almighty. The purpose of Islamic education is intended to achieve long-term goals (general goals / life goals). So that if clearly understood then the aim of Islamic religious education is nothing but the life goal of humans themselves.

According to Daulay (2014: 83) there are seven goals of Islamic education based on the desired aspects, namely: (1) the objectives of the divine and moral aspects, namely to invite people to know God, believe in Him, and stay away from His prohibitions, and foster noble morals, (2) the purpose of the aspects of reason and science, which is to help students think scientifically, because children need to be taught various kinds of science, (3) the purpose of physical education aspects, is to be able to maintain and maintain good health in accordance with their needs, (4) the purpose of social aspects, namely making people aware that they are individual and social creatures so they can understand their position as individual and social creatures, (5) the purpose of the psychological aspects, educating students to have a healthy soul, protected from all types of psychiatric disorders and various other mental illnesses, (6) the purpose of the aspect of beauty, instilling a beautiful sense of humanity that will and bring people more to appreciate the greatness and beauty of God the Creator, and (7) the purpose of the aspect of job creation, which is to equip students to work.

Budiharjo (2005: 1) explains the learning method is a way to present material to students to achieve certain learning goals. Not much different from the general learning methods, Islamic learning methods also vary even there are similarities between the methods of general education with Islamic education methods.

Saleh (1990: 205) states that there are several methods that can be used in learning, including: (1) lecture and story methods, namely methods carried out by conveying the understanding of learning materials to students by way of illumination and verbal narration, (2) the method of 
discussion, question and answer or dialogue, which is a way of delivering learning by way of discussion. Doing questions and answers between the teacher and students so that between teacher and students there is effective communication, (3) the method of parables or metaphors, the method carried out by explaining abstract concepts with concrete meaning so as to provide a clear picture for students, and (4) the method of punishment, namely the method carried out by giving punishment to students. The punishment method is the worst method of the other methods, but giving punishment under certain conditions is also needed in order to cause a deterrent effect for students.

Zuhairini (1981 80) describes the word media as a plural form of the word medium which means an intermediary or introduction. Hamalik (1986: 23) explains that education media are tools, methods and techniques used in order to make communication and interaction more effective between teachers and students in the process of education and teaching in schools.

Boang in Supiana (2011: 5) explained in Arabic, the character is defined as "khulq, Sajiyah, thab'u" (character, character or character). Sometimes also interpreted syakhsiyyah which means closer to personality (personality). Character is the mental, moral or moral characteristics that distinguish one person from another person (KBBI, 2012: 42).

In term, character can be understood as values of human behavior related to God Almighty, self, fellow human beings, environment, and nationality manifested in thoughts, attitudes, feelings, words, and actions based on religious norms, law , manners, culture, and customs (Gunawan, 2012: 2).

Character can also be interpreted by marking and focusing on how to apply the values of goodness in everyday behavior. Good values are categorized as good / noble characters, while bad values are categorized as bad characters. Including good characters such as; good behavior, honest, and helpful to say as people who have good character or noble. Moderate ugly characters like; dishonest, cheating, cruel, and greedy. From some of the notions of character above it can be understood that character is a person's nature in applying good values such as: good behavior, honest, helpful, and others in real daily life (Mulyasa, 2011:3).

Character as the morals of a nation, so that a nation with character is a nation of morality and character and vice versa a nation without 
character is a nation that has no character (Sukri: 2011). Samani and Haryanto (2012: 42), character is interpreted in terms of terminology, as human nature in general that depends on the factors of their own lives. Furthermore, the character is also referred to as the mental, moral, or character traits that characterize a person or group of people.

Character education is a system of inculcating character values to school members which includes the components of knowledge, awareness or will, and actions for those values. Character education in essence wants to shape the individual into a moral person who can live his freedom and responsibility, in his relationships with others and his world in the education community.

Thus character education is always directed towards the formation of moral individuals, capable of making decisions that appear in their behavior, as well as being able to play an active role in building a life together (Fihris, 2010: 23-24). The values of character education come from religion, Pancasila, culture, and national education goals (Puskur, 2011: 3).

Character education is efforts that are designed and carried out systematically to instill the values of student behavior related to God Almighty, self, fellow human beings, the environment, and nationality manifested in thoughts, attitudes, feelings, words, and actions based on religious norms, law, etiquette, culture and customs.

In addition, character education is a system of instilling character values for school members which includes components of knowledge, awareness or will, and actions to implement these values (Zainal Aqib \& Ruzak, 2011: 3). Character education is the process of giving guidance to students to become fully human beings who have character in the dimensions of heart, mind, body and taste and intention. Character education is interpreted as value education, character education, moral education, character education that aims to develop students' goals to make good and bad decisions, maintain what is good, and realize that goodness is a daily life with all my heart (Gunawan, 2012: 28).

\section{METHODS}

The research method uses qualitative research, namely research conducted naturally by utilizing researchers as research instruments. The subjects of this study were Islamic Religious Education teachers, principals, and students. Data retrieved through observation, 
documentation, and interviews. Data is analyzed based on data reduction, data presentation, and drawing conclusions.

\section{RESEARCH RESULTS AND DISCUSSION}

In general the program in the context of fostering eight student characters has been carried out by the school as follows:

1. Religious character. The programs carried out in relation to religious character formation are the Dhuhr prayer together, the commemoration of Islamic holidays, the implementation of Dhoha prayer. Through these programs, students develop religious character. This can be seen from the attitudes and behaviors that are obedient in worship in accordance with their religion. Tolerant to adherents of other religions and able to live in harmony. Sswa also has a religious attitude by showing good behavior and actions in accordance with religious teachings.

2. Honest character. The program carried out in relation to fostering honest character is the OSN (national science olympiad) activity in this case students in working on the problems should behave honestly without cheating. In addition, students are always given motivation to act honestly in every homework or other assignments, meaning that they are motivated to always tell the truth, not lie. Through the program, it is hoped that students who have an honest attitude will not tell lies and commit acts that are prohibited in religion.

3. Character tolerance. The program carried out in relation to fostering tolerance character is the implementation of Dhuha prayer, Zuhr prayer in congregation, commemoration of Islamic holidays, where in its implementation it is emphasized to students especially those who are Muslim to maintain attitudes and behaviors in carrying out these activities by respecting other religious students, not mocking or anything else that can offend other friends. Through the program students have the character of tolerance which is mutual respect and respect between groups or between individuals in society or in other spheres. Tolerance will avoid discrimination, even though there are many different groups or groups in a community group.

4. The character of hard work. Programs that are carried out in relation to fostering the character of hard work are sports activities, 
art activities, Scout activities, silent reading activities, OSN activities. Through the program students have the character of hard work that is trying wholeheartedly with all their strength to try to get the desire to achieve maximum results. The character of hard work is needed by students in following the next activities with hard work, the goals and ideals to be achieved will be realized.

5. Creative characters. The programs carried out in relation to fostering creative characters are Scout activities, OSN activities and art extracurricular activities such as dancing and drawing. Through the program students are instilled creative values that are creative. Creative character is needed for a student in his life and later life which is getting tougher in competition.

6. Independent character. The programs carried out in relation to independent character development are sports activities, Scout activities, art activities, OSN activities. Through the program students have independence, act on their own abilities, do not depend on others. Independent students are free from dependence on others. In learning independent attitude is certainly very necessary, because learning is a process to give birth to a good habituation and one of the habituations to be achieved is independence, an independent student he will not be easily influenced by others so that if there is someone who influences students to do things bad thing then independent students will not be quickly influenced.

7. Democratic Character. The program carried out in connection with fostering the character of democracy is Scouting activities, in which scouting activities are developed and fostered the democratic character of students through various activities carried out in groups, especially in making joint decisions to do something or complete certain jobs. Through these activities the character of student democracy is built within students by fostering the attitudes of students who prefer to deliberate in deciding a problem so that no one will be hurt. Students who are democratic will not be selfish but prefer to be together. If students already have an attitude of democracy then brawls, fights between students will certainly never happen again.

8. Disciplinary Character. Programs that are carried out in relation to fostering disciplinary character are flag ceremonies, sports 
activities, artistic activities. In practice these activities require students to be disciplined with the timing of the implementation of activities and discipline in obeying the rules that apply in these activities. Through these activities students demonstrate compliance, adherence to values that are believed to be their responsibility. Discipline to be achieved in this case is discipline in carrying out worship as a form of obedience to the religion that is believed.

Based on the implementation of character education in learning in schools through the intraculicular activities above, in terms of the form of its activities according to researchers that in fact there are several implementation of Character Education has existed since before the character education curriculum was launched. In other words the content aspect of the implementation of character education in schools is actually in accordance with the guidelines for the development of Character Education as issued by the Ministry of National Education (2010: 20), namely the implementation of character education in subjects developing religious character values, honesty, tolerance, discipline, hard work, creative, independent, democratic, curiosity, national spirit, love of the motherland, respect for achievement, friendly / communicative, love peace, love to read, care for the environment, care for the social, and responsibility in learning in class.

The implementation of character education through extracurricular activities, namely the existence of the Spiritual Organization of Islam (Rohis) in Schools and the extracurricular reading of the Koran and social service. The implementation of Character Education through the Rohis organization in the school can design several work programs and be developed by Rohis which indirectly contains (eighteen) character values as explained above. The implementation of character education through the school Rohis for the value of religious character is very appropriate. Students get more leverage in carrying out the teachings of Islam, namely the midday prayers, asr in congregation, midday prayers, Friday prayers. Especially in practice, students are given the opportunity to manage it. So from here, they have an independent nature.

Learning is carried out by integrating learning material with the teacher's habituation of students. The teacher makes the process of learning in the classroom more an example of the devotion to students so students can mimic what is done by the teacher, so students are more 
interesting and easier to understand. Students are invited to discuss directly the daily lives of students with the environment and are associated with grades religious values being studied.

Learning activities are also observed through observation activities. Researchers conducted observations on learning activities using indicators as follows; (1) applying methods that involve students actively through demonstrations, discussions, simulations, role playing, assignments, observations, and projects, (2) developing the latest things that happen in the community especially related to character problems, (3) getting used to with good behavior so that students can be emulated, also take advantage of the school environment as a medium and learning tool to discuss the learning material being discussed, (4) developing learning indicators and assessment instruments. (5) teachers involve parents as well as educators and the community related to the implementation of Islamic holidays, (6) conducting discussions and communication with students' parents related to student development at school. and (7) teachers also socialize and communicate learning programs and creativity through various media such as wall magazines.

Furthermore, in the formation of student character, teachers can form the character of their students based on the values of character education in schools, which are always integrated into subjects in the learning process in the classroom and in the school environment. The values of character education are based on subjects, because in these subjects have their own values in the teachings of Islam. In the Islamic Religious Education curriculum structure, there are 5 materials taught to students, namely the Qur'an, Aqeedah, Morals, Jurisprudence, and Islamic Culture and Date.

The teacher also elaborates the basic values of character education into the subjects is one way the teacher to shape the character of students in the learning process. In the class the teacher also teaches students that emphasizes the cognitive domain (knowledge), effective (feelings and attitudes), without leaving the values contained in the cognitive domain (rational thinking), and psychomotor (skills) that have relevance to their character education values. While outside the learning process, the tendency to shape the character of students through extracurricular activities held at school. Nevertheless, a teacher can identify all the factors that cause students to disobey school rules. These factors are identified by the teacher from their students in the class so that the teacher can take 
honest approaches in conveying the subjects he teaches to overcome these problems. Therefore, in the teachings of Islam can be used as a basic material in the formation of student character.

Research findings related to the implications of the implementation of the strategies made by teachers in the formation of eight student characters can be seen from the formed characters displayed by students after learning for example; politeness that they speak politely to friends and teachers, ask permission when leaving the class during learning and ask permission to go to school because there is something necessary, caring attitude towards friends [they display mutual help to help in resolving the burden of his friend's difficulties for example by collecting sunbangan money when there are misfortune events experienced by other students ".

Based on the description above, it can be seen that the implementation of learning can obtain positive changes through the implementation of strategies made by the teacher. In this case the teacher carries out learning in accordance with the vision and mission and goals of the school by integrating learning that is carried out by forming eight characters.

Positive changes experienced can also be known through observations made by researchers during the study by using the following indicators: (1) students are involved in maintaining the building and the school environment, among others; clean class picket, clean friday, class cleanliness contest, garden maintenance activities by each class, and others. This trains the character of responsibility and care, (2) students maintain the cleanliness of the school. This is a form of character for environmental stewardship, and (3) extracurricular activities that are used for learning related to fostering the character of discipline, responsibility and care.

The implications of the strategy implemented by the teacher in fostering eight student characters are also evident from: (1) students doing $3 \mathrm{~S}$ (smiles, greetings, greetings) conducted at school, such as when in the morning the teacher welcomes students at the school gate with a smile, as well as daily activities others, (2) students clean the school environment in mutual cooperation conducted on Friday morning, (3) students water the flowers together especially the plants managed by each class, (4) students attend the flag ceremony, (5) students follow the midday prayer activities, (5) students take part in the dhuha prayer, (6) students listen to the 
teacher's advice after the Dhuha prayer, (7) students quote the infaq collected is used to help friends who are unfortunate, (8) students reprimand their friends who do actions which damage, and (9) students do NASA (visible garbage pick up), where students who find rubbish in the form of drink bottles throw it in the available trash.

Some of the activities displayed by students at school through observations that researchers do are like cleaning the school environment in a mutual cooperation. The students do mutual cooperation in cleaning up the school environment. There is a daily picket consisting of several people each class on duty on a particular day to carry out mutual cooperation in cleaning the school environment. There is also a weekly or monthly activity done jointly if all students and guided by the teacher to clean the school environment. In conducting mutual cooperation in the school environment students can show a voluntary attitude and actually carry out activities to clean the school environment.

Then the flowering activities are also carried out jointly by the team that has been arranged according to the schedule set. Each student gets a schedule for watering the flowers in turns. Students who get their turn will work together with their group friends to water the flowers according to the teacher's instructions. Following the flag ceremony. Every Monday there is a flag ceremony. Flag ceremony activities were also carried out by a number of students who were assigned to take charge of the committee. Students in one group will divide the tasks in carrying out the scheduled flag ceremony. While other students will be participants of the flag ceremony. Then students also do the activities of reading short surahs on Friday together with being guided by Islamic Religious Education teachers. Then, after reading, the students listened to the tausiyah delivered by Islamic Religious Education teachers. After that, students collect infaq money which will be used as a donation for students who experience adversity or distress.

The response given by students to the actions of their friends in the school environment described above is to appreciate the positive behavior displayed by their friends. Like, when there are friends who can answer the teacher's questions well, students in their class will applaud and praise their friends. When there are friends who get achievements in certain fields other students give congratulations. When a friend helps a troubled student, another friend will praise him. 
The character of hard work, creative and independent is also formed from the implementation of strategies made by the teacher. This can be seen from the achievement of learning outcomes. In this case the learning outcomes obtained by students on learning are done by giving daily tests, oral examinations, written exams, practice exams, and project assessments. Where at the end of each lesson the teacher asks students whether the lesson has been understood, is there material that is not yet understood and the teacher has directly observed the changes experienced by students. besides that, the teacher also gives homework to students, and also gives MID, and UAS.

Teachers are motivated and can use existing facilities, at least in improving their character, they are more concerned with the beauty of the class and the plants that are around it. The success of the Adiwiyata program is expected to be carried out not only in the school environment but wherever we live as a form of concern for the natural environment. Through the results of researchers who have been found, it can be seen that students get grades according to the minimum completeness criteria, students are happy with the learning given by the teacher to students so as to gain new understanding, new attitudes, and new skills in accordance with learning objectives. At the end of the lesson the teacher asks students if the subject matter can be understood, and students answer already understood, if indeed the learning material they already understand, and students answer and ask for learning material if the material is not yet understood by students. Then the teacher explains the learning material again and the students pay attention until they understand.

\section{CONCLUSIONS}

The conclusions that can be drawn from the research findings are: (1) the program conducted by SDN 107405 Sei Rotan has accommodated the coaching of eight student characters (religious, honest, tolerance, hard work, creative, independent, democratic, and disciplined) through the 35 program ( smiles, greetings, greetings, duha prayers, midday prayers in congregation, commemoration of Islamic holidays, flag ceremonies, extracurricular activities (scouting, sports, and art), clean Friday activities, gymnastics, OSN activities, (2) planning by teachers Islamic Religious Education in realizing the eight characters of students at SD Negeri 107405 Sei Rotan is done by teachers by preparing learning plans based on the vision and mission of the school, competency standards, and also 
prepared based on interesting and innovative learning patterns, (3) strategies undertaken by Islamic Religious Education teachers in the coaching of eight characters students were implemented from the implementation of learning in SDN 107405 Sei Rattan went interesting and fun. Students show enthusiastic attitude towards learning carried out by the teacher, and (4) the implication of coaching the eight characters of students is a positive change in the character of students and achievement of learning outcomes.

\section{RECOMMENDATIONS}

Some things that need to be recommended are: (1) School Principals should be able to fulfill various facilities and infrastructure that can support environment-based learning in SDN 107405 Sei Rotan, (2) to Islamic Religion Education teachers so that it can increase innovations in managing learning, so that learning activities can be more interesting and enjoyable, (3) to students so as to increase their learning motivation and learning activities, and (4) to further researchers, so that they can research about the character development of students through different perspectives of their studies with this research .

\section{REFERENCES}

Al-Muktar, Suwarna dkk (2007), Strategi Pembelajaran PKn, Universitas Terbuka.

Arikunto, Suharsimi, (1993) Manajemen Pengajaran Secara manusiawi, Jakarta: Rineka Cipta.

Aqib Zainal Sujak (2011), Panduan dan Aplikasi Pendidikan karakter cet.1; Bandung: YRama Widya

Budiharjo, (2005) Dasar-Dasar Ilmu Politik, Jakarta Gramedia Pustaka.

Daradjat Zakiyah, (1992) Peranan Agama dalam Kesehetan Mental, Jakarta: Masagung.

Gunawan, (2012) Pendidikan Karakter Konsep Dan Implementasi, Jakarta Bumi Aksara.

Muhaimin, (2012) Urgensi Pendidikan Karakter di Indonesia, Jakarta Rieneka Cipta.

Mulyasa E, (2011) Manajemen Pendidikan Karakter, Jakarta: Bumi Aksara..

Ngalim Purwanto, (2000) Psikologi Pendidikan, Bandung Remaja Rosdakarya. 
Rusydi Ananda, Perencanaan Pembelajaran. Medan: LPPPI, 2019.

Saleh Abdullah, (1990). Pengantar Psikologi Umum, Surabaya Usaha Nasional.

Supiana, (2011). Mozaik Pemikiran Islam Bunga Serampa Pemikiran Pendidikan Indonesia, Jakarta Dirjen Dikti

Suryosubroto, (2002). Pembelajaran di Sekolah. Jakarta : Rieneka Cipta

Syah,Muhibbin, (2011) Psikologi Pendidikan, Bandung Remaja Rosdakarya.

Syam Muhammad Noor (1988). Filsafat Pendidikan Islam, Bandung Mizan

Zubaedi. (2011). Desain Pendidikan Karakter. Konsepsi dan Aplikasinya dalam Lembaga Pendidikan. Jakarta: Kencana.

Zuhairini, (1981). Peran Orangtua Dalam Pendidikan Agama, Journal. 